Borneo Journal of Sciences and Technology, Volume (1), Issue (1), Pages: 50-52

DOI: https://doi.org/10.35370/bjost.2019.1.1-10

e-ISSN: 2672-7439

(C) 2018, UCTS Publisher.

Submitted: 25 November 2018

Accepted: 28 November 2018

Published: 31 January 2019

\title{
Preliminary Assessment on Riverine Soil Properties of Sg. Lebir, Kelantan, Peninsular Malaysia
}

\author{
${ }^{1}$ Syafinie Majid, ${ }^{1}$ Noor Jemali, ${ }^{2}$ Mohamad Saiful Sulaiman, ${ }^{1}$ Sadam Kahar, ${ }^{3}$ Shaharlina Rasid, ${ }^{3}$ Ain Talib, \\ ${ }^{3}$ Mastura Rahim, ${ }^{3}$ Shariman Shaharudin, ${ }^{3}$ Nadhirah Rosman and ${ }^{3}$ Syazrol Omar \\ ${ }^{1}$ Faculty of Earth Science, Universiti Malaysia Kelantan, Jeli, 17600, Malaysia \\ ${ }^{2}$ School of Engineering and Technology, University College of Technology Sarawak, Sibu, 96000, \\ Malaysia \\ ${ }^{3}$ Faculty of Bioengineering and Technology, Universiti Malaysia Kelantan, Jeli, 17600, Malaysia
}

\begin{abstract}
Soil is the unconsolidated material in which plants are rooted. Soil texture is determined by the amount of sand, silt and clay in the soil. Understanding soil properties can help to better management and minimize soil disturbance. These soils were collected for soil properties and bulk density along the $55.2 \mathrm{~km}$ of Sg. Lebir. Soil on Earth commonly contains of various particles such as sand, silt and clay. These particles commonly classes by refer to soil textural triangle. $40 \mathrm{~g}$ of air-dried sample diluted into $1000 \mathrm{ml}$ of deionised water were left until the percentage of sand, silt and clay observed then calculated as percentage. As calculated, the mean percentage of sand contained is $66 \%$, clay $17 \%$ and silt $17 \%$. Besides that, it was concluded that most of the soils texture along $55.2 \mathrm{~km} \mathrm{of} \mathrm{Sg}$. Lebir had a sandy loam soil with $\mathrm{pH}$ slightly acidic (6.08) with densities the mean is $0.24 \mathrm{gcm}^{-3}$.
\end{abstract}

Keywords: soil properties, riverine, Sungai Lebir, conservation.

\section{INTRODUCTION}

Riverine zones are widely recognized for their critical role in water regulation and conservation of biodiversity. Clearing of plant species from stream banks can cause an increase of soil erosion and decreased in water quality through the loss of filtration services. It also contributes to the loss of critical species habitat [1]. Riverine areas are the transition zone between the terrestrial environment and rivers. They are characterized by elevated levels of vegetative productivity, high biodiversity and disproportionately by strong influence on the surrounding environment [2].

Influence by low and high water marks, elevated water tables, infrequent flooding and microclimate, the boundaries of the riverine area are difficult to define. As the river shift over time so does the extent of the riverine area. This occurrence eventually creates a new environment for new primary succession. Overlapping variability in soils, disturbance regimes, water tables, in conjunction with temporal variability and successional dynamics creates a diversity of niches.

Soil properties and functions are expected to change over time following a state convergent on intact rainforest ecosystems. Soil type will help to determine how much water reaches the river. Certain soil types such as sandy soils are very free draining and rainfall on sandy soil is likely to be absorbed by the ground. However, soils containing clay can be almost impermeable and therefore rainfall on clay soils will run off and contribute to flood volumes. The study was motivated by the need for restoration of forest cover in water catchments due to the improvements in water quality that can be achieved [3]. A research aimed to generate knowledge of soil properties to direct future reforestation activities.

\section{MATERIALS AND METHODS}

\section{Study area}

Sg. Lebir catchment area is located in the southern part of the State of Kelantan in the upper most north of Peninsular Malaysia with an approximately total catchment area of $2500 \mathrm{~km}^{2}$. Sg. Lebir is $91 \mathrm{~km}$ length and there are eight tributaries (Sg. Pahi, Sg. Sok, Sg. Rek, Sg. Sam, Sg. Terong, Sg. Miak, Sg. Lebir Kechil and $\mathrm{Sg}$. Paloh) along the river which flow through 
Manik Urai up to Kuala Krai before ending adjacent to Kuala Koh as stated in Figure 1.

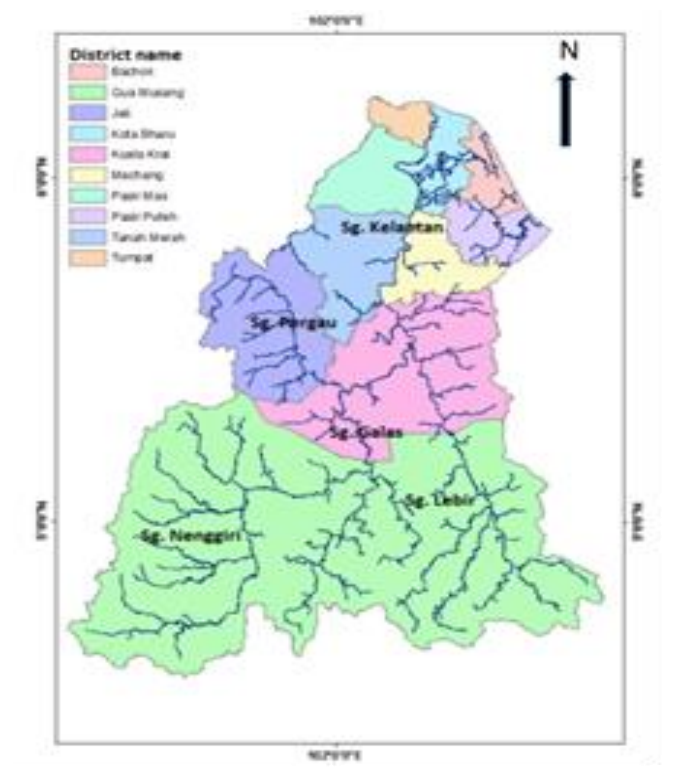

Figure 1: The river which flow through Manik Urai up to Kuala Krai before ending adjacent to Kuala Koh.

\section{Sampling Design}

Field measurements and soil sampling were carried out from $2^{\text {nd }}$ until $6^{\text {th }}$ of March 2017. A total of 17 points were setup randomly along the $55.2 \mathrm{~km}$ of Lebir river. In each point, a $20 \mathrm{~m} \times 20 \mathrm{~m}$ plot was established with $20 \mathrm{~m}$ transect line starting from the river bank. In each site, the following soil procedures were performed: (i) collected a single $8 \mathrm{~cm}$ diameter core to a depth of $30 \mathrm{~cm}$ (textural core) and divided it into $0-15 \mathrm{~cm}$ and $15-$ $30 \mathrm{~cm}$ fractions for textural analysis; and (ii) collected samples of the surface soil using a $12.5 \mathrm{~cm}$ diameter, $8.5 \mathrm{~cm}$ tall, $1043 \mathrm{~cm}^{3}$ volume bulk density ring (bulk density ring) from each of subplots for analysis of physical properties of the soil. Overall, a total of 17 sites with 51 cores were sampled for soil texture and physical analysis.

\section{Texture analysis}

For each sample, $40 \mathrm{~g}$ of air-dried soil was ground and mixed with $1 \mathrm{~L}$ of deionised water. Cylinders were filled to $1 \mathrm{~L}$ with deionised water, mixed with a plunger and left to settle. Using temperature and specific gravity readings, the fraction of sand, silt and clay sized particles in each soil sample was then calculated as a percentage.

\section{Soil physical properties: bulk density}

Soil bulk density was determined from the bulk density ring in each subplot. Fresh soil was oven dried to a constant weight at $105^{\circ} \mathrm{C}$. Soil bulk density is expressed as grams of dry soil per volume. To quantify fine root biomass, soil from one bulk density ring per plot was passed through a sieve $(8 \mathrm{~mm}$ mesh) and roots were manually removed. Roots were then oven dried at $65^{\circ} \mathrm{C}$ to a constant weight, and results expressed as grams of fine roots per kilogram of dry soil.

\section{RESULTS AND DISCUSSION}

\section{Soil properties}

Soil aggregation shows only minor variation among sites and was not considered further in subsequent analyses. Sand sized aggregates: mean $=66 \%$, range $=8$ $90 \%$, clay sized aggregates: mean $=17 \%$, range $=4-54 \%$ and Silt size aggregate: mean $=17 \%$ with range $=4$ $56 \%$. Most of the sites were concluded as sandy loam soil with pH slightly acidic (6.08). It is hypothesized that because of tropical forests are characterized by high rates of rainfall interception and evapotranspiration, it will reduce the soil water content and pore-water pressure causing it to increase. A reduction in the apparent cohesion of riverbank materials from a loss of matric suction will increase the susceptibility of exposed riverbank surface to fluvial scour. Additionally, poor rooted sediment is prone to disaggregation [4]. Particularly, sediment that lack enough cohesion to withstand the boundary shear stresses applied by the near bank current [5]. The used of soil texture triangle in this study is important to determine soil textural class from the percentages of sand, silt, and clay in the soil. The soil texture triangle that gives names associated with various combinations of sand, silt and clay (Figure 2) adapted from Rutgers University was refered in this study. A coarse-textured or sandy soil is one comprised primarily of sand-sized particles. A fine-textured or clayey soil is one dominated by tiny clay particles. Due to the strong physical properties of clay, a soil with only $20 \%$ clay particles behaves as sticky, gummy clayey soil. The term loam refers to a soil with a combination of sand, silt, and clay sized particles. For example, a soil with $30 \%$ clay, $50 \%$ sand, and $20 \%$ silt is called a sandy clay loam. Besides that, soil texture could determines the rate of water drains through a saturated soil or show how water moves more freely through sandy soils. Once field capacity is reached, soil texture could influences amount of water available transferred to the plant. Therefore, most studies proved that clay soils have a greater water holding capacity than sandy soils. In addition, well drained soils typically have good soil aeration where soil could contains air that is similar to atmospheric air, which is conducive to healthy root growth, and thus a produce a healthy trees or crops. 


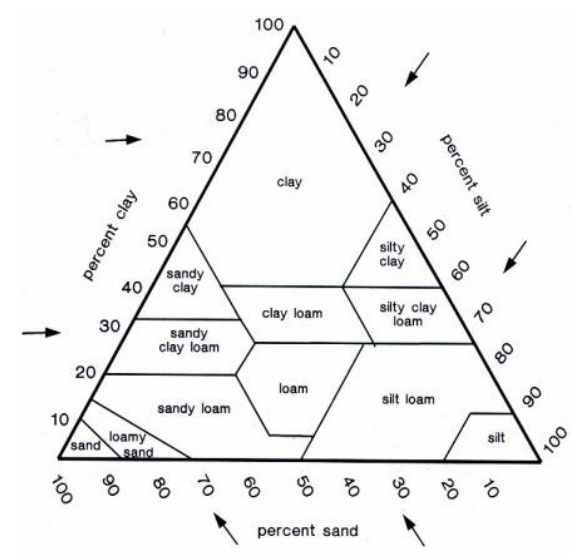

Figure 2: A soil textural triangle use as references which was adapted from Rutgers University and Cornell University

\section{Bulk density}

For bulk densities the mean is $0.24 \mathrm{gcm}^{-3}$ which is rather low. The lower bulk densities are often associated with soil of forests because the greater presence of roots and soil biota, the higher concentrations of organic matter enhance the soil porosity. The high turnover of roots results in more open soil pores as roots grow and subsequently die. Furthermore, forests have a broader range of fine to large woody roots including with larger, woody roots that leave conduits in the soil post death [6]. High soil organic matter is also associated with low bulk density, a trend seen in this study as bulk density was negatively correlated with soil organic carbon (SOC). This was expected as SOC is indicative of litter dynamics, turnover and decomposition rates and is responsible for providing low-density mass to the soil and improving soil structure. The bulk density values in this study are also low in comparison to average soil that is $1.2 \mathrm{gcm}^{-3}$. High porosity and the high organic matter content in the topsoil. We also proposed that the low bulk density contributes to the trend of increasing infiltration rates with time following reforestation as the two variables were inversely correlated.

\section{CONCLUSION}

From the 5 days of expedition, it was concluded the soil texture are sandy loam which $\mathrm{pH} 6.08$. Besides that, by referring to the soil textural triangle, the mean percentage of sand are $66 \%$ and both of silt and clay are $17 \%$. Meanwhile, the mean of bulk densities is 0.24 $\mathrm{gcm}^{-3}$.

\section{ACKNOWLEDGMENT}

We acknowledged research team of Sg. Lebir Scientific Expedition and the Faculty of Earth Science, Universiti Malaysia Kelantan for research facilities and financial provided.

\section{REFERENCES}

[1] Naiman, R.J., De'camps, H. and McClain, M.E. (2005) Riparian: ecology, conservation and management of streamside communities. New York: Academic PressPowers, J.S. and PerezAviles, D. (2012) Edaphic factors are a more important control on surface fine roots than stand age in secondary tropical dry forests. Biotropica 45: $1-9$.

[2] Rodrigues Nogueira Jr. L., de MoraesGoncalves, J.L., Lex Engel, V. and Parrotta J. (2011) Soil dynamics and carbon stocks 10 years after reforestation of degraded land using Atlantic Forest tree species. Forest Syst 20: 536-545.

[3] Wickham, J.D., Wade, T.G. and Riitters, K.H. (2011). Anenvironmental assessment of United States drinking water watersheds. Landscape Ecol 26:605-616.

[4] Dunaway, D., Swanson, S.R., Wendel, J. and Clary,W.(1994) .The effect of herbaceous plant communities and soil texture on particle erosion on alluvial streambanks. Geomorphology. 9. 47-56.

[5] Simon, A. and Collison, J.C. (2002).Quantifying the mechanical and hydrologic effect of riparian vegetation on streambank stability.Earth Surface Processes and Landform.27.527-546.

[6] Fine'r L., Ohashi M., Moguchi K. and Hirano Y. (2011). Factors causing variation in fine root biomass in forest ecosystems. Forest Ecol Manage 261: 265-277. 